\title{
Stabilization Policy and
}

\section{the Costs of Dollarization*}

\author{
Stephanie Schmitt-Grohé ${ }^{\dagger} \quad$ Martín Uribe
}

\begin{abstract}
This paper compares the welfare costs of business cycles in a dollarized economy to those arising in economies in which monetary policy takes the form of inflation targeting, money growth rate pegs, or devaluation rate rules. The analysis is conducted within an optimizing model of a small open economy with sticky prices. The model is calibrated to the Mexican economy and is driven by three external shocks: terms of trade, world interest rate, and import-price inflation. The welfare comparisons suggest that dollarization is the least successful of the monetary policies considered. Agents are willing to give up between 0.1 and 0.3 percent of their nonstochastic steady-state consumption to see a policy other than dollarization implemented.
\end{abstract}

*This paper was sponsored by Instituto Tecnológico Autónomo de México (ITAM) as part of the project Optimal Monetary Institutions for Mexico. We would like to thank for very helpful comments Elisabeth Huybens, Enrique Mendoza, Marco Del Negro, Carlos Noriega, Carlos Zarazaga, and seminar participants at the conference on "Optimal Monetary Institutions for Mexico" held in Mexico in December of 1999 and at the conference on "Global Monetary Integration," held in Cleveland, Ohio in June 2000.

${ }^{\dagger}$ Assistant Professor of Economics at Rutgers University and Research Affiliate, Centre for Economic Policy Research. E-mail: grohe@econ.rutgers.edu.

${ }^{\ddagger}$ Assistant Professor of Economics at the University of Pennsylvania. E-mail: uribe@econ.upenn.edu. 


\section{Introduction}

The idea of replacing the domestic currency with the U.S. dollar is actively being debated in a number of emerging market economies. This is particularly the case in Argentina, Ecuador and Mexico, with Ecuador having taken the most concrete steps towards adoption of the dollar. Proponents of dollarization argue that by eliminating devaluation risk, dollarization will go a long way toward reducing country risk premia, thus lowering aggregate volatility. On the other hand, opponents of dollarization warn that this way of reducing country risk comes at a cost that may very well exceed its benefits. This paper contributes to the dollarization debate by examining one of its potential costs in detail.

At least three sources of costs associated with dollarization have been identified in the literature. One is the loss of seignorage revenue. When a country adopts the U.S. dollar as the sole legal tender, the stream of its seignorage revenue begins to flow to the U.S. central bank. Clearly, the magnitude of the cost of dollarization stemming from the loss of seignorage revenue for emerging market economies depends on their ability to negotiate a seignorage sharing agreement with the United States. In Schmitt-Grohé and Uribe (1999) we show that in the absence of a sharing agreement the present discounted value of seignorage revenue lost due to dollarization is likely to be at least twice a country's pre-dollarization monetary base.

A second source of costs is the lack of a lender of last resort. Under dollarization, the government loses the ability to inject liquidity into the financial system in the event of a banking crisis through money creation. However, as pointed out by Calvo (1999a,b, 2000), domestic banks can have access to liquidity through a variety of sources other than the printing press of the central bank. Therefore, dollarization does not necessarily imply the loss of a lender of last resort but merely the disappearance of one particular source of liquidity, namely central bank credit.

A third source of costs arises from the fact that under dollarization a country relinquishes its ability to conduct cyclical monetary policy. In economies with nominal frictions, monetary 
policy can play an important role in stabilizing business cycles. To the extent that the shocks affecting the dollarized economy are different from those affecting the U.S. economy or affect the two economies asymmetrically, dollarization will come at the cost of higher macroeconomic instability. This is because U.S. monetary policy is likely to respond mainly to that country's state of the business cycle.

The purpose of this paper is to quantify the cost of dollarization arising from this third channel, that is, the reduced ability to accommodate asymmetric shocks. Specifically, we compare the level of welfare in a dollarized economy to the level of welfare in alternative economies that differ from a dollarized economy only in their monetary arrangements. The alternative monetary policy regimes we study belong to three broad families: (i) Devaluationrate rules that set the devaluation rate as a function of the exogenous shocks driving business cycles; (ii) Inflation targeting which we take to imply that the central bank completely stabilizes the rate of inflation of either consumer or nontraded goods prices; and (iii) Money growth rate rules that stipulate a constant rate of expansion of the money supply.

The welfare-based evaluation of the alternative policy regimes involves five steps: the development of a utility-based theoretical framework that provides a metric for judging alternative policy specifications; the identification and estimation of the sources of aggregate fluctuations for the Mexican economy; the calibration of the structural parameters of the model; a comparison of the predictions of the theoretical model to observed business-cycle regularities in Mexico; and the computation of the level of welfare associated with the alternative monetary policy arrangements.

The theoretical framework we use is an extension of a simpler one that has served as the workhorse in open economy macroeconomics since the seminal work of Calvo (1983). Specifically, we develop an optimizing dynamic general equilibrium model of a small open economy with endogenous labor supply and capital accumulation that produces exportables and nontradables and absorbs exportables, importables, and nontradables. In this framework, room for cyclical monetary policy arises from two sources: first, product prices in the 
nontraded sector are assumed to be sticky as in Rotemberg (1982). Second, there is a demand for money which originates from the assumption that real balances facilitate transactions in final goods as in Kimbrough (1986). These two sources of nominal rigidities create a tension for stabilization policy. On the one hand, the presence of sticky prices in the nontraded sector calls for policies that stabilize the nontraded component of CPI inflation. On the other hand, the fact that, via transaction costs, money acts as a tax on aggregate spending creates an incentive for the central bank to stabilize the opportunity cost of holding money, that is, the domestic nominal interest rate.

A recent literature on business cycles in emerging market economies has emphasized external shocks as the predominant source of aggregate fluctuations. For example, Calvo, Leiderman, and Reinhart (1993) study the comovement between real exchange rates and U.S. interest rates for 10 Latin American countries between 1988 and 1992 and find that around half of the variance in real exchange rates can be explained by variations in U.S. interest rates. In a study of the Mexican economy, Del Negro and Obiols-Homs (2000) confirm these results by showing that over the period 1970 to 1997 most shocks to output and prices originated in the foreign sector in the form of shocks to U.S. industrial production, interest rates, and consumer and commodity prices. Mendoza (1995) presents a model-based evaluation of the contribution of terms-of-trade shocks to explaining output variability in developing countries and concludes that this type of shock accounts for around half of the variance of GDP. Based on this body of evidence, we focus on three external shocks as the principal sources of aggregate uncertainty: world-interest-rate, terms-of-trade, and world inflation shocks.

We estimate the stochastic processes followed by these three shocks using data from the Mexican economy. The estimated processes serve as the driving force of business cycles in our theoretical model. To gage the relative importance of the external shocks for observed Mexican business-cycle fluctuations, we perform a variance decomposition analysis of the Mexican real exchange rate and output. We find that more than 45 percent of the 8 - to 
16-quarter-ahead forecasting error variance of these two variables can be explained by our three external shocks.

We calibrate our model to the Mexican economy using long-run data restrictions for the post-debt-crisis era. We then compare observations on the comovements between key macroeconomic aggregates, such as output, consumption, investment, inflation, and the real exchange rate, over the period 1988-1994 to the predictions of the calibrated model to show that it explains Mexican business-cycle regularities well. Based on this result, we argue that the model economy studied in this paper is a relevant framework for evaluating the welfare consequences for Mexico of dollarization and of other monetary regimes.

The analysis of the welfare costs for the Mexican economy of alternative monetary policy arrangements yields the following three results: First, dollarization is more costly than any of the alternative nonestimated monetary policies considered. Consumers are willing to give up between one tenth and one third of one percent of their steady-state consumption to see a policy other than dollarization implemented. Second, of the policies we consider, the best is one in which the central bank adopts a devaluation rate rule that stipulates an increase in the rate of devaluation in response to a rise in the world interest rate, a decline in the terms of trade, or a reduction in the inflation rate of imports. We find that the optimal rule within this class is "hyperactive" because it calls for a very large world interest rate response coefficient of 26. An ad-hoc, conceivably more plausible specification with an interest rate coefficient of 2 still produces welfare costs significantly lower than those associated with dollarization. Taken at face value, these two results provide a lower bound for the size of benefits that are required to make dollarization a socially viable proposal.

Third, the cost of business cycles during the Pacto period, 1988-1994, was about one third of one percent of the steady-state stream of consumption. This figure is comparable to that estimated by Lucas (1987) for the U.S. economy over a sample ending at the beginning of the Second World War. Lucas's welfare cost estimate is to a large extend the result of the fact that his prewar sample includes the Great Depression years, which were characterized 
by high aggregate volatility. By comparison, the welfare costs of business cycles during the Pacto era are more than three times as large as the upper bound that Lucas reports for the U.S. economy over the period following the Second World War.

The remainder of the paper is organized in six sections. Section 2 presents the theoretical model, section 3 identifies the exogenous shocks generating aggregate fluctuations in Mexico and estimates their stochastic process. Section 4 describes the calibration of the structural parameters of the model. Section 5 compares the model's prediction regarding the relative volatility, correlation with output, and serial correlation of output, consumption, investment, and inflation to the actual comovements in these variables observed in Mexico over the period 1988-1994. Section 6 evaluates the welfare costs of Mexican business cycles under a number of different monetary stabilization policies and section 7 concludes the paper with a critical evaluation of the ability of dollarization to act as a commitment device.

\section{A small open economy with sticky prices}

We consider a small open economy with free access to international capital markets that produces two types of goods, exportables and nontradables, and absorbs three types of goods, exportables, importables, and nontradables. The economy features two sources of nominal rigidities. One originates in the nontraded sector, where production takes place under imperfectly competitive conditions and nominal prices adjust sluggishly. The other arises because purchases of final goods are assumed to be subject to a proportional transaction cost that is decreasing in the buyer's holdings of monetary balances. Business cycles are driven by exogenous, stochastic innovations in the terms of trade, the world interest rate, and foreign inflation. 


\subsection{The private sector}

The economy is populated by a large number of infinitely-lived households. Preferences are defined over processes of consumption, $c_{t}$, and labor effort, $h_{t}$, and are described by the following utility function:

$$
E_{0} \sum_{t=0}^{\infty} \beta^{t} U\left(c_{t}, h_{t}\right),
$$

where $E_{t}$ denotes the mathematical expectation conditional on information available in period $t, \beta \in(0,1)$ denotes the subjective discount factor, and $U$ takes the particular form

$$
U(c, h)=\frac{\left[c^{\nu}(1-h)^{1-\nu}\right]^{1-\sigma}}{1-\sigma},
$$

with $\sigma \geq 0$ and $\nu \in(0,1)$.

Households have access to two financial assets: domestic money, $M_{t}$, and a foreigncurrency denominated bond, $B_{t}$, that pays the gross interest rate $r_{t}$ between periods $t$ and $t+1$. In addition, households can hold physical capital, $k_{t}$. Capital depreciates at the constant rate $\delta \in(0,1)$ per period and is subject to convex adjustment costs. Specifically, the law of motion of $k_{t}$ is given by

$$
k_{t+1}=(1-\delta) k_{t}+\phi\left(\frac{i_{t}}{k_{t}}\right) k_{t},
$$

where $i_{t}$ denotes gross investment and $\phi$ is an increasing and concave function satisfying $\phi(\delta)=\delta$ and $\phi^{\prime}(\delta)=1$. We introduce capital adjustment costs to avoid the excess volatility of investment that typically arises in small open economy models (see Schmitt-Grohé, 1998).

Following Kimbrough (1986), domestic money demand is motivated by assuming that purchases of final goods are subject to a proportional transaction cost, $s\left(v_{t}\right)$, that is increasing in money velocity, $v_{t}$. To ensure that money velocity is strictly increasing in the nominal interest rate, we assume that the transaction cost function satisfies $2 s^{\prime}+v s^{\prime \prime}>0$. Money 
velocity is defined as

$$
v_{t}=\frac{p_{t}\left(c_{t}+i_{t}\right)}{m_{t}}
$$

where final goods prices, $p_{t}$, and real balances, $m_{t}$, are expressed in units of importable goods, that is, letting $P_{t}$ and $P_{t}^{m}$ be the price of final and importable goods in terms of domestic currency, $p_{t} \equiv P_{t} / P_{t}^{m}$ and $m_{t} \equiv M_{t} / P_{t}^{m}$.

We assume that in the nontraded sector nominal prices adjust sluggishly. Each household is assumed to be the monopolistic supplier of a differentiated nontraded good. As in Rotemberg (1982), households face convex adjustment costs when they change the nominal price of the nontraded good they produce. The representative household's period-by-period budget constraint is given by

$$
p_{t}\left(c_{t}+i_{t}\right)\left(1+s\left(v_{t}\right)\right)+m_{t}+b_{t}+\tau_{t} \leq \frac{m_{t-1}}{\pi_{t}^{m}}+\frac{r_{t-1} b_{t-1}}{\pi_{t}^{m *}}+u_{t} k_{t}+w_{t}\left(h_{t}-\tilde{h}_{t}^{n}\right)+\tilde{p}_{t}^{n} F^{n}\left(\tilde{h}_{t}^{n}\right)-\theta\left(\tilde{\pi}_{t}^{n}\right) .
$$

The left-hand side of (5) represents the uses of wealth in period $t$ expressed in terms of importables: consumption and investment purchases (including transaction costs), real balances, and real bond holdings, $b_{t} \equiv B_{t} / P_{t}^{m *}$, with $P_{t}^{m *}$ denoting the foreign-currency price of importables, and real payments of lump-sum taxes, $\tau_{t}$. The right-hand side of (5) represents the sources of wealth. Each period $t \geq 0$, the household starts with money balances carried over from the pervious period, whose real value is given by $M_{t-1} / P_{t}^{m}=m_{t-1} / \pi_{t}^{m}$, where $\pi_{t}^{m} \equiv P_{t}^{m} / P_{t-1}^{m}$ denotes domestic import price inflation. The household also receives the principal and interest on bonds acquired in period $t-1$ in the amount of $r_{t-1} b_{t-1} / \pi_{t}^{m *}$, where $\pi_{t}^{m *} \equiv P_{t}^{m *} / P_{t-1}^{m *}$ is the foreign import price inflation. In addition, the right-hand side of (5) includes the household's current income, which consists of income from the rental of physical capital, wage earnings for hours worked outside the household, and sales of nontradables net of the cost of price adjustment. The variables $u_{t}$ and $w_{t}$ denote, respectively, the wage rate and the rental rate of capital, both expressed in terms of importables. The variable $\tilde{p}_{t}^{n} \equiv \tilde{P}_{t}^{n} / P_{t}^{m}$ denotes the relative price of the differentiated nontraded good produced by the 
household in terms of importables, with $\tilde{P}_{t}^{n}$ representing the nominal price of that good.

The function $\theta(\cdot)$ measures the cost of changing nominal prices and thus reflects the degree of nominal price stickiness. It is assumed to be strictly convex in the gross rate of inflation of the differentiated good produced by the household, $\tilde{\pi}_{t}^{n} \equiv \tilde{P}_{t}^{n} / \tilde{P}_{t-1}^{n}$. Note that $\tilde{\pi}_{t}^{n}$ can be written as:

$$
\tilde{\pi}_{t}^{n} \equiv \frac{\tilde{p}_{t}^{n}}{\tilde{p}_{t-1}^{n}} \pi_{t}^{m}
$$

We assume that $\theta\left(\pi^{n}\right)=0$, where $\pi^{n}$ denotes the nonstochastic steady-state inflation rate of nontradables. This assumption implies that in steady state price stickiness imposes no resource costs on households. In addition, we require that $\theta^{\prime}\left(\pi^{n}\right)=0$, which implies, as will become clear shortly, that in the nonstochastic steady state households set prices so as to equate marginal cost to marginal revenue.

The technology used to produce the differentiated nontraded good takes the form $F^{n}\left(\tilde{h}_{t}^{n}\right)=$ $\left(\tilde{h}_{t}^{n}\right)^{\omega}, 0<\omega<1$. The variable $\tilde{h}_{t}^{n}$ denotes hours allocated by the household to the production of the differentiated nontraded good. The household faces the demand function $q_{t}^{n} d\left(\tilde{p}_{t}^{n} / p_{t}^{n}\right)$, where $q_{t}^{n}$ denotes the level of aggregate demand for nontradables, $p_{t}^{n}$ is a price index of nontradables expressed in terms of importables, and $d(\cdot)$ is a positive and decreasing function satisfying $d(1)=1$ and $d^{\prime}(1)<-1$. Such a demand function can be derived by assuming that final nontradable goods are a composite produced from differentiated intermediate goods via a Dixit-Stiglitz production function. The restriction imposed on $d^{\prime}(1)$ is necessary for the household's price-setting problem to be well defined in a symmetric equilibrium. The individual household takes both $q_{t}^{n}$ and $p_{t}^{n}$ as given. Finally, we assume that households must set nominal prices one period in advance and that current output is demand determined, that is,

$$
F^{n}\left(\tilde{h}_{t}^{n}\right)=q_{t}^{n} d\left(\frac{\tilde{p}_{t}^{n}}{p_{t}^{n}}\right)
$$

The household chooses the set of stochastic processes $\left\{c_{t}, h_{t}, \tilde{h}_{t}^{n}, k_{t+1}, b_{t}, m_{t}, i_{t}, \tilde{p}_{t+1}^{n}\right.$, $\left.\tilde{\pi}_{t+1}^{n}\right\}_{t=0}^{\infty}$ so as to maximize (1) subject to (3)-(7) and some borrowing limit that prevents 
it from engaging in Ponzi-type schemes taking as given the sequences $\left\{p_{t}, p_{t}^{n}, q_{t}^{n}, u_{t}, w_{t}\right.$, $\left.r_{t-1}, \pi_{t}^{m}, \pi_{t}^{m *}\right\}_{t=0}^{\infty}$ and the initial conditions $k_{0}, b_{-1}, \tilde{p}_{0}^{n}$, and $\tilde{\pi}_{0}^{n}$. The associated first-order conditions are

$$
\begin{gathered}
U_{c}\left(c_{t}, h_{t}\right)=\lambda_{t} p_{t}\left[1+s\left(v_{t}\right)+v_{t} s^{\prime}\left(v_{t}\right)\right] \\
-\frac{U_{h}\left(c_{t}, h_{t}\right)}{U_{c}\left(c_{t}, h_{t}\right)}=\frac{w_{t}}{p_{t}}\left[1+s\left(v_{t}\right)+v_{t} s^{\prime}\left(v_{t}\right)\right]^{-1} \\
\lambda_{t}=\beta E_{t} \lambda_{t+1}\left(\frac{r_{t}}{\pi_{t+1}^{m *}}\right) \\
1-v_{t}^{2} s^{\prime}\left(v_{t}\right)=\beta E_{t}\left(\frac{\lambda_{t+1}}{\lambda_{t}} \frac{1}{\pi_{t+1}^{m}}\right) \\
p_{t}\left[1+s\left(v_{t}\right)+v_{t} s^{\prime}\left(v_{t}\right)\right]=\mu_{t}^{k} \phi^{\prime}\left(\frac{i_{t}}{k_{t}}\right) \\
\mu_{t}^{k}=\beta E_{t} \frac{\lambda_{t+1}}{\lambda_{t}}\left\{\begin{array}{c}
\left.u_{t+1}+\mu_{t+1}^{k}\left[1-\delta+\phi\left(\frac{i_{t+1}}{k_{t+1}}\right)-\phi^{\prime}\left(\frac{i_{t+1}}{k_{t+1}}\right) \frac{i_{t+1}}{k_{t+1}}\right]\right\} \\
E_{t} \lambda_{t+1} \theta^{\prime}\left(\tilde{\pi}_{t+1}^{n}\right) \tilde{\pi}_{t+1}^{n}=\beta E_{t} \lambda_{t+2} \theta^{\prime}\left(\tilde{\pi}_{t+2}^{n}\right) \tilde{\pi}_{t+2}^{n}+E_{t} \lambda_{t+1} F^{n}\left(\tilde{h}_{t+1}^{n}\right) \frac{m r_{t+1}-m r_{t+1}}{m r_{t+1} / \tilde{p}_{t+1}^{n}-1}
\end{array}\right.
\end{gathered}
$$

The variable $\lambda_{t}$ is the Lagrange multiplier on the budget constraint (5) and represents the marginal utility of wealth in terms of importables. The right-hand side of equation (11) is the reciprocal of the gross nominal interest rate on domestic risk-free bonds. Equation (11) therefore implies that money velocity is determined solely by the nominal interest rate and is strictly increasing in this variable. Equations (9) and (12) show that the opportunity cost of holding money acts as a tax on both effort and investment. The variable $\mu_{t}^{k} \lambda_{t}$ is the Lagrange multiplier on the law of motion of physical capital, equation (3). Thus $\mu_{t}^{k}$ represents the shadow price of installed capital in terms of importables, or Tobin's Q. Equation (12) then says that gross investment is increasing in Tobin's $Q$. In equation (14), $m r_{t}$ and $m c_{t}$ denote, 
respectively, marginal revenue and marginal cost, which are defined as

$$
\begin{gathered}
m r_{t}=\tilde{p}_{t}^{n}\left[1+\frac{d\left(\frac{\tilde{p}_{t}^{n}}{p_{t}^{n}}\right)}{d^{\prime}\left(\frac{\tilde{p}_{t}^{n}}{p_{t}^{n}}\right) \frac{\tilde{p}_{t}^{n}}{p_{t}^{n}}}\right] \\
m c_{t}=\frac{w_{t}}{F^{n^{\prime}}\left(\tilde{h}_{t}^{n}\right)}
\end{gathered}
$$

Hence equation (14) shows that the presence of nominal rigidities induces the firm to deviate from equating marginal cost to marginal revenue.

Final goods are assumed to be a composite of nontradable, exportable, and importable goods produced with a technology of the form

$$
q_{t}^{f}=F^{f}\left(a_{t}^{n}, a_{t}^{x}, a_{t}^{m}\right)
$$

where $a_{t}^{n}, a_{t}^{x}$, and $a_{t}^{m}$ denote, respectively, domestic absorption of nontradable, exportable, and importable goods in period $t$. The production technology is assumed to be of the form $F^{f}\left(a^{n}, a^{x}, a^{m}\right)=\left(a^{n}\right)^{\alpha^{n}}\left(a^{x}\right)^{\alpha^{x}}\left(a^{m}\right)^{\alpha^{m}}$, with $\alpha^{i}>0$ for $i=n, x, m$ and $\alpha^{n}+\alpha^{x}+\alpha^{m}=1$. The market for final goods is perfectly competitive and prices are fully flexible. Thus, the representative firm's demands for inputs satisfy

$$
\begin{aligned}
& p_{t} F_{n}^{f}\left(a_{t}^{n}, a_{t}^{x}, a_{t}^{m}\right)=p_{t}^{n} \\
& p_{t} F_{x}^{f}\left(a_{t}^{n}, a_{t}^{x}, a_{t}^{m}\right)=p_{t}^{x} \\
& p_{t} F_{m}^{f}\left(a_{t}^{n}, a_{t}^{x}, a_{t}^{m}\right)=1,
\end{aligned}
$$

where $F_{i}^{f}$ denotes the partial derivative of $F^{f}$ with respect to $a^{i}$ for $i=n, x, m$ and $p_{t}^{x} \equiv$ $P_{t}^{x} / P_{t}^{m}$ denotes the relative price of exportables in terms of importables, or the terms of trade.

Like the final goods producing sector, the sector producing export goods is perfectly 
competitive and prices are fully flexible. Exportable output, $q_{t}^{x}$, is produced using capital, $k_{t}$, and labor services, $h_{t}^{x}$, according to the following technology:

$$
q_{t}^{x}=F^{x}\left(k_{t}, h_{t}^{x}\right)
$$

where $F^{x}(k, h)=k^{\alpha^{k}} h^{1-\alpha^{k}}, 0<\alpha^{k}<1$. Each period, firms choose capital and labor services so as to maximize profits, which are given by $p_{t}^{x} F^{x}\left(k_{t}, h_{t}^{x}\right)-u_{t} k_{t}-w_{t} h_{t}^{x}$. Input demands must then satisfy the following efficiency conditions:

$$
p_{t}^{x} F_{k}^{x}\left(k_{t}, h_{t}^{x}\right)=u_{t}
$$

and

$$
p_{t}^{x} F_{h}^{x}\left(k_{t}, h_{t}^{x}\right)=w_{t}
$$

\subsection{The government}

\subsubsection{Monetary Policy}

The baseline monetary policy specification considered in this paper is dollarization. Abstracting from its implications for seignorage revenue and shoe-leather costs, dollarization can be interpreted as a perfectly credible peg of the devaluation rate. Accordingly, we model dollarization as

$$
\epsilon_{t}=\bar{\epsilon} \quad \forall t
$$

where $\epsilon_{t}$ denotes the gross devaluation rate of the domestic currency, which is given by $\mathcal{E}_{t} / \mathcal{E}_{t-1}$, where $\mathcal{E}_{t}$ denotes the nominal exchange rate, defined as the price of one U.S. dollar in terms of Mexican pesos.

In addition to dollarization, we consider five other monetary specifications. The first is one in which the central bank directly controls the monetary aggregate by setting the growth 
rate of the money supply. Specifically, we consider simple rules of the type

$$
M_{t}=(1+\zeta) M_{t-1}
$$

where $\zeta$ is the rate of expansion of the money supply. This monetary policy is often regarded as the polar case to dollarization for it allows the nominal exchange rate to float freely.

The second alternative monetary policy regime we consider is inflation targeting. This kind of policy has recently been advocated, on theoretical grounds, by a number authors, notably Svensson $(1997,1999)$, and has been put into practice by central banks in several countries, such as New Zealand and Australia. We assume that inflation targeting takes the form of a constant CPI inflation rate. ${ }^{1}$ Letting $\pi_{t} \equiv P_{t} / P_{t-1}$ denote gross CPI inflation and $\bar{\pi}$ the inflation target, inflation targeting takes the form

$$
\pi_{t}=\bar{\pi} \quad \forall t
$$

Third, we study the stabilizing properties of a monetary policy that eliminates all inefficiencies stemming from nominal price rigidities. Specifically, we analyze a policy that ensures that in the nontraded sector marginal cost equals marginal revenue at all times and under all circumstances:

$$
m r_{t}=m c_{t}
$$

If one restricts attention to small fluctuations around the non-stochastic steady state, as we do throughout our analysis, this policy regime implies that the government completely stabilizes inflation of nontradables, $\pi_{t+1}^{n}=\bar{\pi}^{n}, \forall t \geq 0$, where $\bar{\pi}^{n}$ is some constant inflation target (recall that $\pi_{t+1}^{n}$ is in the information set of period $\left.t\right) .{ }^{2}$ In models in which sluggish price adjustment is the only source of nominal frictions, the monetary policy given in (27) corresponds to the optimal monetary policy. ${ }^{3}$

Fourth, we investigate the dynamic properties of devaluation-rate rules whereby the rate 
of devaluation of the domestic currency is set as a linear function of the exogenous variables driving business cycles in the economy under consideration, namely, the terms of trade, $p_{t}^{x}$, import price inflation, $\pi_{t}^{m *}$, and the world interest rate, $r_{t}^{*}$. That is,

$$
\widehat{\epsilon}_{t}=\alpha^{p^{x}} \widehat{p}_{t}^{x}+\alpha^{\pi^{m}} \widehat{\pi}_{t}^{m *}+\alpha^{r} \widehat{r}_{t}^{*}
$$

where $\widehat{x}_{t} \equiv \ln \left(x_{t} / \bar{x}\right)$ denotes the log-deviation of $x_{t}$ from its nonstochastic steady-state value $\bar{x}$. The coefficients $\alpha^{i}, i=p^{x}, \pi^{m}, r$ are chosen so as to minimize the welfare costs of business cycles. The choice of the left-hand-side variable in the above monetary policy rule is meant to reflect the fact that in developing countries, and particularly in Latin America, policymakers have traditionally favored the devaluation rate as the monetary policy instrument (see, for example, Calvo and Reinhart, 2000; and Kiguel and Liviatan, 1992).

Finally, we consider the following stochastic version of (24)

$$
\epsilon_{t}=\bar{\epsilon} e^{\eta_{t}^{\epsilon}}
$$

where $\eta_{t}^{\epsilon}$ is a mean-zero i.i.d. shock. As we argue below, this type of rule describes Mexican monetary policy during the period 1988:Q2-1994:Q3 over which the exchange-rate stabilization program known as the Pacto de Solidaridad Económica was in place. We are particularly interested in this period of Mexican economic history because it represents a relatively long span of time over which monetary policy was fairly homogenous. We use the Pacto era as a point of reference to assess the model's ability to account for actual Mexican fluctuations.

\subsubsection{Fiscal Policy}

For simplicity, we assume that government consumption and government bond holdings are zero at all times. In this case, the consolidated government budget constraint can be written as

$$
\tau_{t}=m_{t}-\frac{m_{t-1}}{\pi_{t}^{m}}
$$


The assumed fiscal policy implies that the government rebates seignorage revenues to the public through lump-sum transfers.

\subsection{Equilibrium}

In a symmetric equilibrium, all firms in the nontraded goods sector set identical prices and quantities, so that $\tilde{p}_{t}^{n}=p_{t}^{n}, \tilde{h}_{t}^{n}=h_{t}^{n}$, and $\tilde{\pi}_{t}^{n}=\pi_{t}^{n}$. The definition of inflation of nontradables given in (6) then implies that

$$
\pi_{t}^{n}=\frac{p_{t}^{n}}{p_{t-1}^{n}} \pi_{t}^{m}
$$

In turn, equations (7) and (14)-(16) can be written as:

$$
\begin{gathered}
q_{t}^{n}=F^{n}\left(h_{t}^{n}\right) \\
E_{t} \lambda_{t+1} \theta^{\prime}\left(\pi_{t+1}^{n}\right) \pi_{t+1}^{n}= \\
\quad \beta E_{t} \lambda_{t+2} \theta^{\prime}\left(\pi_{t+2}^{n}\right) \pi_{t+2}^{n} \\
-\frac{1+\mu}{\mu} E_{t} \lambda_{t+1} q_{t+1}^{n}\left[m r_{t+1}-m c_{t+1}\right], \\
m r_{t}=\frac{p_{t}^{n}}{1+\mu},
\end{gathered}
$$

and

$$
m c_{t}=\frac{w_{t}}{F^{n^{\prime}}\left(h_{t}^{n}\right)}
$$

where $1+\mu \equiv d^{\prime}(1) /\left(1+d^{\prime}(1)\right)$ is the steady-state markup of prices over marginal cost in the nontraded sector. Market clearing in the labor, nontraded, and final goods markets implies that:

$$
\begin{gathered}
h_{t}=h_{t}^{x}+h_{t}^{n} \\
q_{t}^{n}=a_{t}^{n}+\frac{\theta\left(\pi_{t}^{n}\right)}{p_{t}^{n}} \\
q_{t}^{f}=\left(c_{t}+i_{t}\right)\left(1+s\left(v_{t}\right)\right)
\end{gathered}
$$


In equilibrium, the stock of foreign bonds evolves according to the following equation:

$$
b_{t}=\frac{r_{t-1}}{\pi_{t}^{m *}} b_{t-1}+t b_{t},
$$

where $t b_{t}$ denotes the trade balance in units of importables in period $t$ and is given by

$$
t b_{t}=p_{t}^{x}\left(q_{t}^{x}-a_{t}^{x}\right)-a_{t}^{m}
$$

We assume that the law of one price holds for tradable goods, that is, the domestic prices of importables and exportables, $P_{t}^{m}$ and $P_{t}^{x}$, are linked to the respective world prices, $P_{t}^{m *}$ and $P_{t}^{x *}$, by the relationships $P_{t}^{x}=\mathcal{E}_{t} P_{t}^{x *}$ and $P_{t}^{m}=\mathcal{E}_{t} P_{t}^{m *}$. The domestic economy takes world prices as exogenous. The first of the above relationships implies that domestic import price inflation equals the sum of foreign import price inflation and the devaluation rate, that is,

$$
\pi_{t}^{m}=\epsilon_{t} \pi_{t}^{m *}
$$

Consumer price inflation is defined as

$$
\pi_{t}=\frac{p_{t}}{p_{t-1}} \pi_{t}^{m}
$$

Finally, we assume that the nominal interest rate at which the country can borrow internationally is given by the world interest rate plus a premium. The size of the interest rate premium is assumed to be increasing in the country's stock of foreign debt. Specifically, the gross interest rate on foreign-currency denominated bonds is given by

$$
r_{t}=r_{t}^{*} \rho\left(-b_{t}\right),
$$

where $r_{t}^{*}$ denotes the gross world interest rate and is taken as exogenous by the country, and $\rho(\cdot)$ is a positive and increasing function. The reason for introducing a debt elastic interest 
rate premium is technical. As is well known, small open economies that face a purely exogenous world interest rate display nonstationary dynamics in response to stationary exogenous shocks. As a result, the solution to the log-linearized equilibrium conditions may not be a valid approximation to the exact, nonlinear equilibrium system. Since we wish to employ log-linear solution methods to characterize the equilibrium dynamics, we must eliminate any source of nonstationarity. One way to do so is to assume a variable interest rate premium as in (43). To ensure that at business-cycle frequencies the model behaves as if the interest rate premium was constant, in the numerical experiments we set the debt elasticity of the interest rate premium very close to zero.

We define a stationary rational expectations equilibrium under dollarization as a set of stationary stochastic processes $\left\{v_{t}, p_{t}, c_{t}, i_{t}, m_{t}, h_{t}, \lambda_{t}, \mu_{t}^{k}, w_{t}, u_{t}, q_{t}^{x}, k_{t+1}, h_{t}^{x}, q_{t}^{f}, h_{t}^{n}, t b_{t}\right.$, $\left.b_{t}, a_{t}^{x}, a_{t}^{m}, a_{t}^{n}, q_{t}^{n}, p_{t}^{n}, \pi_{t+1}^{n}, \epsilon_{t}, r_{t}, \pi_{t}^{m}, \pi_{t}, m r_{t}, m c_{t}\right\}_{t=0}^{\infty}$ satisfying (3)-(4), (8)-(13), (17)-(24), and (31)-(43), given exogenous processes $\left\{\pi_{t}^{m *}, p_{t}^{x}, r_{t}^{*}\right\}_{t=0}^{\infty}$ and initial conditions $k_{0}, b_{-1}, \pi_{0}^{n}$, $r_{-1}$, and $p_{-1}^{n}$. Equilibrium under any of the other four monetary policy regimes discussed above can be defined in a similar manner by replacing in the above definition equation (24) with the appropriate monetary specification.

Two macroeconomic indicators we focus on are gross domestic product, $g d p_{t}$ and the real exchange rate, $e_{t}$. Gross domestic product is defined as the value of all goods produced in the economy in terms of final goods; formally,

$$
g d p_{t}=\frac{p_{t}^{x} q_{t}^{x}+p_{t}^{n} q_{t}^{n}}{p_{t}}
$$

The real exchange rate is defined as the relative price of tradables in terms of consumption. Letting $p_{t}^{T}$ denote the relative price of tradables in terms of import goods, we have that the real exchange rate, $e_{t}$ is given by ${ }^{4}$

$$
e_{t}=\frac{p_{t}^{T}}{p_{t}}
$$

We characterize the equilibrium dynamics by solving a log-linear approximation to the 
equilibrium conditions around the nonstochastic steady state. To this end, we calibrate the model to the Mexican economy. The calibration exercise involves two tasks. One is the estimation of the stochastic process of the exogenous shocks representing the sources of aggregate fluctuations. The second is the use of long-run data and model restrictions to identify the deep structural parameters of the model.

\section{Sources of aggregate fluctuations in the Mexican econ- omy}

We now turn to the estimation of the law of motion of the three external sources of uncertainty that drive business cycles in our model economy: the terms of trade, the world interest rate, and import price inflation. As mentioned earlier, our choice of shocks is guided by the results of a number of recent studies pointing at the fact that external shocks explain a significant fraction of aggregate fluctuations in developing countries in general (Calvo, Leiderman, and Reinhart, 1993) and in Mexico in particular (Del Negro and Obiols-Homs, 2000). In this section, we provide evidence corroborating the results of these studies. Specifically, we estimate the share of the k-quarter-ahead forecasting error variance in Mexican value added and the Mexican real exchange rate that is explained by our three foreign shocks.

The empirical model is a vector auto regression in the cyclical components of the logarithms of the terms of trade, $\widehat{p}_{t}^{x}$, gross import price inflation, $\widehat{\pi}_{t}^{m *}$, gross world nominal interest rates, $\widehat{r}_{t}^{*}$, real gross domestic product, $\widehat{y}_{t}$, and the Peso/dollar real exchange rate, $\widehat{e}_{t}$. Our sample consists of quarterly observations beginning in the first quarter of 1987 and ending in the second quarter of 1999 . We measure the terms of trade as the ratio of dollar export prices to dollar import prices for Mexico. Our measure of import-price inflation is the 3-month geometric mean of the monthly change in the dollar import price index of Mexico. The world nominal interest rate is taken to be the constant maturity yield on 3-month U.S. Treasury bills. Mexican real output is measured by gross domestic product at constant 
1993 prices. The real exchange rate is measured as the ratio of the U.S. CPI index to the corresponding Mexican index adjusted by the nominal exchange rate. ${ }^{5}$

The evolution of the external shocks is assumed to be exogenous to the Mexican economy. In addition, we assume that innovations to import price inflation do not affect the terms of trade contemporaneously and that innovations to the 3-month Treasury bill rate have no contemporaneous effect on either Mexican terms of trade or Mexican import price inflation. These identification assumptions give rise to the following block recursive structure of the empirical model:

$$
\left[\begin{array}{cc}
\mathbf{a}_{11} & \mathbf{0}_{3 \times 2} \\
\mathbf{a}_{21} & \mathbf{a}_{22}
\end{array}\right]\left(\begin{array}{c}
\widehat{p}_{t}^{x} \\
\widehat{\pi}_{t}^{m *} \\
\widehat{r}_{t}^{*} \\
\widehat{y}_{t} \\
\widehat{e}_{t}
\end{array}\right)=\left[\begin{array}{cc}
\mathbf{b}_{11}(L) & \mathbf{0}_{3 \times 2} \\
\mathbf{b}_{21}(L) & \mathbf{b}_{22}(L)
\end{array}\right]\left(\begin{array}{c}
\widehat{p}_{t-1}^{x} \\
\widehat{\pi}_{t-1}^{m *} \\
\widehat{r}_{t-1}^{*} \\
\widehat{y}_{t-1} \\
\widehat{e}_{t-1}
\end{array}\right)+\left(\begin{array}{c}
\epsilon_{t}^{p^{x}} \\
\epsilon_{t}^{\pi^{m *}} \\
\epsilon_{t}^{r^{*}} \\
\epsilon_{t}^{y} \\
\epsilon_{t}^{e}
\end{array}\right),
$$

where $\mathbf{a}_{11}$ and $\mathbf{a}_{22}$ are lower triangular matrices whose diagonal elements are equal to 1. The disturbance vector $\left(\epsilon_{t}^{p^{x}}, \epsilon_{t}^{\pi^{m *}}, \epsilon_{t}^{r^{*}}, \epsilon_{t}^{y}, \epsilon_{t}^{e}\right)$ has mean zero and diagonal variance/covariance matrix $\Sigma$. Based on a likelihood ratio test, we include four lags in the vector autoregression. ${ }^{6}$ The external bloc of the VAR system, formed by the first three equations of (44), serves as the driving force of aggregate fluctuations in the theoretical model. Table 6 in the appendix presents the estimated coefficients of this bloc.

Table 1 shows the fraction of the k-quarter ahead forecasting error variance of output and the real exchange rate explained by the three external shocks and the two domestic shocks. At a horizon of 8 quarters, about half of the forecasting error variance of output is due to external shocks. At horizons of 3 years or longer, the fraction of the forecasting error variance of output explained by external shocks is around 2/3. External shocks explain about half of the variance of the real exchange rate forecasting errors at horizons of 8 quarters or longer. We interpret these results as suggesting that in Mexico over the past 12 years, the three 
external shocks that are assumed to drive business cycles in our theoretical model explain a large fraction of the observed aggregate fluctuations in Mexico at business-cycle frequencies.

Of the three external shocks we consider, the world interest rate plays the most important role in explaining output fluctuations. At all horizons, innovations in the world interest rate account for more than half of the forecasting error variance of Mexican output explained by external shocks. At the same time, both the world interest rate and terms of trade appear to be important determinants of the observed movements in the real exchange rate. At all horizons, about half of the variance of forecasting errors due to external shocks is attributable to terms of trade shocks and one third to world interest rate shocks.

\section{Calibration}

We calibrate the model to the Mexican economy. The log-linear approximation to the equilibrium conditions involves 16 free parameters, whose assigned values are presented in table 2 , and 17 implied parameters, whose values are shown in table 3. The time unit is chosen to be a quarter. Following Mendoza and Uribe (2000), we set the share of traded value added in GDP to 44.2 percent, the investment share in GDP to 21.7 percent, the trade balance share in GDP to 3.6 percent, the labor share in the traded sector to 26.1 percent, the labor share in the nontraded sector to 35.9 percent, the average world real interest rate to 6.5 percent per year, and the labor-leisure ratio to 0.25 . We use the money demand estimates for Mexico presented in Mendoza and Uribe (2000) to set the log-log interest elasticity of money demand to -0.16 . The steady-state GDP velocity was set at 3.92 per quarter, which corresponds to the average of the ratio of nominal GDP to nominal M1 over the Pacto era. The steady-state devaluation rate was set at 1.57 percent per quarter, which corresponds to the average devaluation rate of the Mexican peso/US dollar exchange rate observed over the period 1988:2-1994:3. We assign a value of 24.0 percent to the share of exports to GDP, to match the average of this ratio in the Mexican economy over the period 1993-1999. The 
consumption elasticity of the marginal utility of consumption was set to -5 drawing on an empirical study by Reinhart and Végh (1995).

There is little empirical evidence on the degrees of imperfect competition and price stickiness in developing countries and in particular in the Mexican economy. Thus, as a first pass, we set the average markup of price over marginal cost in the nontraded sector to 10 percent, which is consistent with estimates for the U.S. economy (e.g., Basu and Fernald, 1997). To calibrate the degree of price stickiness, we use Sbordone's (1998) estimate of a linear newKeynesian Phillips curve. Such a Phillips curve arises in our model from a log-linearization of equilibrium condition (33):

$$
E_{t} \widehat{\pi}_{t+1}^{n}=\beta E_{t} \widehat{\pi}_{t+2}^{n}-\frac{1}{\eta_{\theta} \mu}\left(E_{t} \widehat{p}_{t+1}^{n}-E_{t} \widehat{m c}_{t+1}\right),
$$

where $\eta_{\theta}$ is a positive parameter increasing in $\theta^{\prime \prime}\left(\pi^{n}\right)$. Using U.S. data, Sbordone finds that $\eta_{\theta} \mu$ equals 17.5, which, given our assumption that $\mu=0.1$, implies that $\eta_{\theta}$ equals 175 . As pointed out by Sbordone, in a Calvo-Yun staggered price setting model, this value of $\eta_{\theta}$ implies that firms change their price on average every 9 months. In the context of our model, this calibration of the degree of price stickiness implies that in response to a once-and-for-all devaluation of the Mexican peso, the adjustment of the Mexican CPI achieves 42 percent of its long-run adjustment in the first quarter and 91 percent after 4 quarters.

We set the elasticity of Tobin's $Q$ with respect to investment at 0.13 , so as to match the observed volatility of investment of 12 percent over the Pacto era. In computing the volatility of investment predicted by the theoretical model, we use our estimate of Mexican monetary policy over the Pacto era, which is presented in the next section. Finally, we assume that the debt elasticity of the country premium is equal to $10^{-5}$. As explained earlier, we pick such a small number to ensure that at business-cycle frequencies the economy behaves as if the country premium was constant. 


\section{$5 \quad$ Actual and predicted comovements}

We compare the aggregate comovements implied by the model to those observed in Mexico during the Pacto era (1988:Q2-1994:Q3). We choose this period because it is characterized by a fairly homogeneous monetary policy regime. Specifically, during the Pacto era, the Mexican government followed a managed exchange rate regime. Although, as pointed out by Santaella and Vela (1996), the management of the exchange rate during the Pacto took a number of different forms, including subperiods with a fixed exchange rate, a preannounced rate of devaluation, and an exchange rate band, on net the rate of devaluation exhibited a fairly stable behavior. Indeed in the literature on disinflation in developing countries, the Pacto is considered a prime example of orthodox exchange-rate-based stabilization (see Rebelo and Végh, 1995 and the references cited therein). We model the behavior of the devaluation rate during the Pacto era as following an i.i.d. process like the one described in equation (29). Our estimate of that specification yields:

$$
\ln \epsilon_{t}=0.0157+\eta_{t}^{\epsilon} ; \quad \sigma_{\eta^{\epsilon}}=0.0145
$$

The estimated value of $\sigma_{\eta^{\epsilon}}$ is small compared to the standard deviation of the devaluation rate observed in the pre- and post-Pacto years. The standard deviation of $\epsilon_{t}$ was 0.1154 during the period 1976:1-1988:1 and 0.1043 during the period 1994:4-1999:3.

To compute the comovement among key macroeconomic variables implied by the model, we feed the above monetary policy and the estimated process for the external variables given in table 6 into the calibrated and log-linearized version of the model presented in section 2 . We then construct artificial time series of length 500 using nonstochastic steady-state values as initial conditions. We compute sample second moments from the last 26 observations of each artificial time series. Thus, implied second moments are computed from time series that have the same length in quarters as the ones used in calculating observed second moments. ${ }^{7}$ We repeat this procedure 1000 times and calculate the average of the sample second moments. 
The cyclical components of actual data are measured as percentage deviations from a loglinear time trend. ${ }^{8}$ Second moments for all variables were computed using the 26 observations of the Pacto era.

In our model economy consumption is a nondurable good. However, for the Pacto era, only data on total consumption expenditures is available at a quarterly frequency. Total consumption includes expenditures on consumer durables as well as on nondurables and services. Consumption of durable goods is significantly more volatile than that of nondurables and services. For example, in the period 1993:1-1999:2, for which disaggregated consumption data is available, the ratio of the variance of nondurables and services to the variance of total consumption was 0.52 . We approximate the standard deviation of nondurable consumption during the Pacto era by the product of this ratio and the standard deviation of total consumption. ${ }^{9}$

Table 4 presents the comovements of output, consumption, investment, CPI inflation, the trade balance share, and the real exchange rate observed in the Mexican economy during the Pacto era and those predicted by the theoretical economy. The model is broadly consistent with the data. Specifically, it captures well the volatility of output, consumption, and inflation, but slightly overpredicts the volatility of the trade-balance-to-GDP ratio and underpredicts the volatility of the real exchange rate. ${ }^{10}$ In addition, the model correctly implies that consumption, investment and inflation are positively correlated with output and that the trade balance share is acyclical. The main counterfactual prediction of the model concerns the cyclical behavior of the real exchange rate. In the data this variable is uncorrelated with output, whereas the model predicts a large positive correlation. Overall, our model captures the comovements of macroeconomic aggregates in the Pacto era sufficiently well to make the welfare comparisons of alternative monetary policies that we present in the next section meaningful.

Before moving on, we wish to stress that the focus on the Pacto era is limited to this section. It is motivated by the need to find a period with a homogeneous monetary policy in 
Mexico in order to be able to make a sensible comparison between the observed fluctuations and those predicted by the theoretical model. An alternative strategy to evaluate the fit of the model economy, not pursued in this paper, is to estimate a regime switching process for monetary policy. The potential advantage of such strategy would be to allow the use of longer time series evidence to construct observed second moments. A drawback of this approach is that it forces the model builder to make an assumption about the predicted or unanticipated nature of every policy switch. ${ }^{11}$

\section{The welfare cost of dollarization}

We are now ready to asses the welfare consequences of dollarization as compared to other possible monetary arrangements. We conduct the welfare analysis using the theoretical model developed in section 2 and calibrated in section 4. The sources of uncertainty driving business cycles are the three external shocks, terms of trade, import price inflation, and world interest rate, whose law of motion is estimated in section 3 .

We measure the welfare costs of business cycles associated with a particular monetary policy regime by the fraction of nonstochastic steady-state consumption that households would be willing to give up in order to be indifferent between the corresponding constant sequences of consumption and hours and the equilibrium stochastic processes for these two variables associated with the monetary policy under consideration. Formally, letting $c$ and $h$ denote the nonstochastic steady-state values of consumption and hours and $\left\{c_{t}, h_{t}\right\}$ the equilibrium stochastic processes of consumption and hours corresponding to a particular monetary policy, we measure the cost of business cycles under such policy by the number $\xi$ such that

$$
U((1-\xi) c, h)=E\left\{U\left(c_{t}, h_{t}\right)\right\}
$$

where $E$ denotes the unconditional mathematical expectation. According to this expression, the business cycles associated with a particular monetary policy are costly if $\xi$ is positive 
and beneficial if $\xi$ is negative. We approximate $\xi$ by taking a second-order Taylor expansion of the above expression with respect to $\left(\ln c_{t}, \ln h_{t}\right)$ around $(\ln c, \ln h)$. In addition, we use the approximation $E \ln \left(y_{t} / y\right)=0$ for $y_{t}=c_{t}, h_{t}$. Then, defining $x_{t}=c_{t}^{\nu}\left(1-h_{t}\right)^{1-\nu}$, $\xi$ is given by

$$
\xi=1-\left[1+\frac{(1-\sigma)^{2}}{2} \operatorname{Var}\left(\hat{x}_{t}\right)\right]^{\frac{1}{\nu(1-\sigma)}}
$$

where, as explained earlier, a hat on a variable denotes its log-deviation from the nonstochastic steady state and $\operatorname{Var}\left(\hat{x}_{t}\right)$ denotes the unconditional variance of $\hat{x}_{t}$. If $\sigma>1$, welfare costs are increasing in $\operatorname{Var}\left(\widehat{x}_{t}\right)$. Table 5 presents the welfare costs associated with seven alternative monetary policies. The welfare costs are comparable across policies because all policies are specified in such a way that they give rise to the same nonstochastic steady state. The policies considered are those described in section 2.2.

The welfare gain of eliminating business cycles under the monetary policy in place during the Pacto era is 0.33 percent of steady-state consumption. This number is more than three times as large as the upper bound found by Lucas (1987) for the U.S. economy over the period following the Second World War. The welfare cost we find is comparable in magnitude to that reported by Lucas for the U.S. over the period prior to the Second World War. There are, however, two methodological differences between Lucas' calculations and ours. One is that Lucas uses actual data whereas we use data implied by a theoretical model. The other difference is that Lucas assumes that the single-period utility function depends on total consumption whereas we assume that it depends on nondurable consumption and leisure. A problem in evaluating equation (45) using Mexican data is that until 1993 Mexico did not publish disaggregated consumption data and that no time series on hours worked is available. If one uses total consumption expenditures over the Pacto period and assumes that hours are constant, then one obtains a value of $\xi$ of 0.51 percent. If instead one corrects the volatility of total consumption to proxy for the volatility of nondurables as described in section 5 , then the value of $\xi$ drops to 0.27 percent. Our model predicts a number that falls between these two figures. ${ }^{12}$ 
The main result that arises from the horse race presented in table 5 is that dollarization is welfare inferior to any of the alternative nonestimated policies considered. Households are willing to give up between 0.09 and 0.26 percent of their nonstochastic steady-state consumption to see a policy other than dollarization implemented. ${ }^{13}$ The intuition behind this result is simple. Consider the effect of an increase in the world interest rate - the most important source of movements in Mexican output. In response to such a shock, aggregate demand falls. The decline in aggregate demand triggers a fall in the relative price of nontradables in terms of tradables because in the short run the supply of nontradables is less than perfectly elastic. Under dollarization, the nominal price of tradables cannot adjust because it is exogenously given from abroad. Thus, the decline in the relative price of nontradables would have to come about through a decline in the nominal price of nontradables. However, this price adjustment is not possible in the model studied here, because prices in the nontraded sector are sticky. The rigidity in the relative price of nontradables that arises from the combination of dollarization and nominal price stickiness exacerbates the contraction in the nontraded sector compared to the one that would arise were prices not sticky. It follows that if the monetary authority could respond to the adverse interest rate shock by devaluing the domestic currency, then the relative price of nontradables would be allowed to fall, making the adjustment of the sticky price economy more akin to that of a flexible-price economy. This is the essential reason why in the present model dollarization is welfare inferior to a flexible exchange rate.

Indeed, a depreciation of the nominal exchange rate is precisely what happens in response to an adverse world interest rate shock under all of the alternative nonestimated monetary policies considered in table 5. This is the reason why these policies are associated with lower welfare costs than dollarization. We illustrate this intuition in figure 1, which shows the response of domestic absorption, nontraded output, the relative price of nontradables in terms of importables, and the devaluation rate to a one percent increase in the world interest rate. To facilitate the understanding of the model's dynamics, the impulse responses are 
constructed assuming that the world interest rate follows a univariate $\operatorname{AR}(1)$ process with a serial correlation coefficient of 0.9. Each row compares the dynamic adjustment under dollarization (dashed line) with that under an alternative monetary policy (solid line). The impulse responses are expressed as log-deviations from steady state. (So, for example, 0.01 means that a variable is one percent above its steady-state value.)

Consider, for example, the case of a money growth rate peg. The decline in aggregate demand induced by the interest rate hike produces a contraction in the demand for real balances. Given the supply of nominal balances, the adjustment in the money market must take place through an increase in the price level. Because the price of nontradables is sticky and the foreign currency price of tradables is exogenous, the entire adjustment in the price level comes about via a depreciation of the nominal exchange rate. The mechanisms that lead to an initial depreciation of the nominal exchange rate under the other monetary policies considered are different but have an equally straightforward intuitive interpretation.

The best monetary policy specification considered is a devaluation rate rule of the form given in (28), where the coefficients were picked so as to minimize the welfare costs of business cycles. This is a 'constrained optimal' rule in the sense that it is the best within the class of devaluation rate rules that depend on $\widehat{p}_{t}^{x}, \widehat{\pi}_{t}^{m *}$ and $\widehat{r}_{t}^{*}$. The signs of the coefficients are what one would intuitively expect: the monetary authority devalues in response to a decline in the terms of trade, a decline in import price inflation, or an increase in the world interest rate. The intuition behind the benefits of such a devaluation rule should be clear from our above discussion regarding the real rigidity that dollarization introduces in our model. The constrained optimal devaluation rule calls for an extremely aggressive response of the devaluation rate to changes in the world interest rate. When the world interest rate increases by one percentage point, the devaluation rate is jacked up by 26 percentage points. This "hyperactive" policy stance, though optimal, seems unlikely to be adopted in practice. Thus, we include in table 5 an ad hoc rule that maintains the coefficients on $p^{x}$ and $\pi^{m *}$ prescribed by the constrained optimal rule, but assigns a much smaller, and conceivably 
more implementable value of 2 to the interest rate coefficient. In this case the welfare cost of business cycles is still significantly smaller than that under dollarization and comparable to that associated with inflation or money growth targeting.

It is noteworthy that the monetary policy that eliminates all inefficiencies stemming from sluggish price adjustment in the nontraded sector, namely, nontraded inflation targeting, has higher welfare costs than several of the other policies considered. Under this policy, marginal revenue equals marginal cost at all times. Thus, the economy behaves just like an economy without sticky prices. The reason why this policy does not have the lowest welfare costs is that while it eliminates the distortions associated with sluggish price adjustment it fails to neutralize the other distortion of the model that stem from transaction costs.

We wish to close this section with a word of caution. The welfare cost estimates presented are based on second-order approximations to the utility function and first-order approximations to the decision rules. As illustrated by Kim and Kim (1998) in certain economic environments such approximation may lead to spurious welfare rankings. It is therefore safer to interpret the results of this section simply as an investigation into the ability of the alternative monetary arrangements to reduce the volatility of $x_{t}$, the argument of the single-period utility function. It would be worthwhile investigating the sensitivity of the results obtained in this section to higher order approximations to the decision rules.

\section{$7 \quad$ Final Remarks}

In the welfare comparisons presented in this paper, the government is assumed to be able to perfectly commit to the implementation of any of the monetary policies considered. Our results may therefore be regarded as naive. After all, the reason why many observers favor dollarization is its assumed ability to tie the hands of governments too weak to resist the temptation of the printing press. However, the question of commitment could also be turned around: Is it not naive to believe that a chronically indisciplined government would alter its 
behavior merely because of a change in currency? Would such a government not simply get rid of dollarization at the first strong desire to inflate? Alternatively, would a government that has solved its fundamental fiscal problems not be as prepared to stick to dollarization as to any other low-inflation monetary policy, particularly if the alternative policies yield higher welfare? Clearly, these are issues that have yet to be explored, both empirically and theoretically.

A natural and potentially fertile ground for understanding the nature of government commitment to dollarization is monetary and fiscal behavior at the provincial level. To a large extent, a national currency is to a province what the U.S. dollar is to a dollarized country. In developing countries, the emergence of provincial money is not a rare phenomenon. For example, because the Argentine peso is legal tender in Argentina, its provinces can be considered "pesoized" economies. However, over the last two decades, a number of provincial governments in the northwestern region of Argentina have introduced local currencies. A case in point is the issuance of the CECOR in the province of Córdoba (Fig. 2). In the mid 1990s, after having been hit hard by the Tequila effect, the government of Córdoba-the second most important province from an economic point of view after the province of Buenos Aires - was in financial dire straits. Having failed to meet wage payments for a number of months, the provincial government was facing an economic crisis of major proportions that was threatening to degenerate into social chaos. As a way to circumvent its serious liquidity crunch, the government of Córdoba decided to pay wages and other current financial obligations with a provincial bond called CECOR explictly issued for this purpose. ${ }^{14}$ As soon as the CECOR was introduced, it began to play the quintessential role of money: medium of exchange. The CECOR rapidly assumed money's other two classical functions of store of value and unit of account.

By putting the CECOR in circulation, the government of Córdoba was in effect abandoning a monetary arrangement that featured the peso as the only medium of exchange. A number of important lessons can be learned from the CECOR episode: (i) Deviating from 
dollarization is likely to occur at a point at which not only the government but also the public perceives the regime shift as beneficial. In Córdoba, the CECOR introduced much needed liquidity in the midst of an unprecedented credit crisis; (ii) Governments can reintroduce domestic currencies almost effortlessly and clearly do not need to create a central bank first. The most likely scenario is that the Treasury department will simply print low-denomination government bonds and use them to pay for current government expenditures. Thus, all that is needed is a printing press and some government obligations; (iii) A 'domestic' currency can circulate even if the foreign currency maintains its status as legal tender. Indeed, during its existence, the CECOR was Córdoba's primary medium of exchange.

But perhaps the most important lesson that can be learned from experiences like the CECOR in Córdoba is that the superiority of adopting a foreign currency over other conventional monetary arrangements as a commitment mechanism should not be taken for granted. 


\section{References}

Basu, Susanto, and John G. Fernald. "Returns to Scale in U.S. Production: Estimates and Implications." Journal of Political Economy 105 (April 1997), 249-83.

Baxter, Marianne, and Mario J. Crucini. "Business Cycles and the Asset Structure of Foreign Trade." International Economic Review 36 (November 1995), 821-854.

Calvo, Guillermo A. "On Models of Money and Perfect Foresight." International Economic Review 29 (February 1979), 83-103.

Calvo, Guillermo A. "Staggered prices in a utility-maximizing framework." Journal of Monetary Economics 12 (1983), 383-98.

Calvo, Guillermo A. "Testimony on Full Dollarization." University of Maryland, April 1999a.

Calvo, Guillermo A. "On Dollarization." University of Maryland, April 1999b.

Calvo, Guillermo A. "Capital Markets and the Exchange Rate with Special Reference to the Dollarization Debate in Latin America." Journal of Money, Credit, and Banking, forthcoming 2000 .

Calvo, Guillermo A., Leonardo Leiderman, and Carmen M. Reinhart. "Capital Inflows and Real Exchange Rate Appreciation in Latin America: The Role of External Factors." International Monetary Fund Staff Papers 40 (March 1993), 108-151.

Calvo, Guillermo A. and Carmen M. Reinhart. "Fear of Floating." mimeo, University of Maryland, May 2000.

Del Negro, Marco, and Francesc Obiols-Homs. "Has Monetary Policy been So Bad That It Is Better To Get Rid of It? The Case of Mexico." Journal of Money, Credit, and Banking, forthcoming 2000.

Galí, Jordi, and Tommaso Monacelli. "Optimal Monetary Policy and Exchange Rate Volatility in a Small Open Economy." mimeo Universitat Pompeu Fabra, May 2000.

Kiguel, Miguel A., and Nissan Liviatan. "The Business Cycle Associated with Exchange Rate-Based Stabilizations." World Bank Economic Review 6 (May 1992), 279-305. 
Kim, Jinill, and Henry Kim. "Inaccuracy of Log-linear Approximation in Welfare Calculation: The Case of International Risk Sharing." mimeo, University of Virginia, 1998.

Kimbrough, Kent P. "The Optimum Quantity of Money Rule in the Theory of Public Finance." Journal of Monetary Economics 18 (November 1986), 277-84.

Lucas, Robert E, Jr. Models of business cycles. Yrjo Jahnsson Lectures series. London and New York: Blackwell, 1987.

Mendoza, Enrique G. "The Terms of Trade, the Real Exchange Rate, and Economic Fluctuations." International Economic Review 36 (February 1995), 101-137.

Mendoza, Enrique G., and Martín Uribe. "Devaluation Risk and the Syndrome of ExchangeRate-Based Stabilizations." Carnegie-Rochester Conference Series on Public Policy, forthcoming, 2000.

Rebelo, Sergio T. "Inflation in Fixed Exchange Rate Regimes: The Recent Portuguese Experience." In Francisco Torres and Francesco Giavazzi, edited by Adjustment and growth in the European Monetary Union, pp. 128-49. Oxford; New York and Melbourne: Cambridge University Press, 1993.

Rebelo, Sergio T., and Carlos A. Végh. "Real Effects of Exchange-Rate-Based Stabilization: An Analysis of Competing Theories." In Ben S. Bernanke and Julio J. Rotemberg, edited by NBER Macroeconomics Annual 1995, pp. 125-174. Cambridge, Mass.: MIT Press, 1995.

Reinhart, Carmen M., and Carlos A. Végh. "Nominal Interest Rates, Consumption Booms, and Lack of Credibility: A Quantitative Examination." Journal of Development Economics 46 (April 1995), 357-378.

Rotemberg, Julio J. "Sticky prices in the United States." Journal of Political Economy 90 (1982), 1187-1211.

Rotemberg, Julio J., and Michael Woodford. "Interest Rate Rules in an Estimated Sticky Price Model." In Monetary Policy Rules, edited by John B. Taylor, pp. 57-119. Chicago, 
IL: University of Chicago Press, 1999.

Santaella, Julio A., and Abraham E. Vela. "The 1987 Mexican Disinflation Program: An Exchange Rate-Based Stabilization?." IMF working paper 96-24, March 1996.

Sbordone, Argia. "Prices and unit labor costs: A new test of price stickiness." mimeo, Rutgers University, 1998.

Schmitt-Grohé, Stephanie. "The International Transmission of Economic Fluctuations: Effects of U.S. Business Cycles on the Canadian Economy." Journal of International Economics 44 (1998), 257-287.

Schmitt-Grohé, Stephanie and Martín Uribe. "Dollarization and Seignorage: How Much is at Stake?." University of Pennsylvania, July 1999. [Available at http://www. econ. upenn. edu/ ${ }^{\sim}$ uribe].

Svensson, Leo E.O. "Inflation Forecast Targeting: Implementing and Monitoring Inflation Targets." European Economic Review 41 (1997), 1111-1146.

Svensson, Leo E.O. "Inflation Targeting as a Monetary Policy Rule." Journal of Monetary Economics 43 (June 1999), 607-654.

Uribe, Martín. "Exchange-Rate-Based Inflation Stabilization: The Initial Real Effects of Credible Plans." Journal of Monetary Economics 39 (June 1997), 197-221.

Uribe, Martín. "The Analytics of Credible Exchange-Rate-Based Disinflation When Money Facilitates Firms' Transactions." working paper University of Pennsylvania, January 2000. [Available at http://www.econ.upenn.edu/ ${ }^{\sim}$ uribe] 


\section{Appendix}

\section{Estimate of the law of motion of the exogenous external shocks}

The first three equations of the VAR system given in (44) are

$$
\mathbf{a}_{11}\left(\begin{array}{c}
\widehat{p}_{t}^{x} \\
\widehat{\pi}_{t}^{m *} \\
\widehat{r}_{t}^{*}
\end{array}\right)=\mathbf{b}_{11}(L)\left(\begin{array}{c}
\widehat{p}_{t-1}^{x} \\
\widehat{\pi}_{t-1}^{m *} \\
\widehat{r}_{t-1}^{*}
\end{array}\right)+\left(\begin{array}{c}
\epsilon_{t}^{p^{x}} \\
\epsilon_{t}^{\pi^{m *}} \\
\epsilon_{t}^{r^{*}}
\end{array}\right) .
$$

Premultiplying by the inverse of the lower triangular matrix $\mathbf{a}_{11}$ yields

$$
\left(\begin{array}{c}
\widehat{p}_{t}^{x} \\
\widehat{\pi}_{t}^{m *} \\
\widehat{r}_{t}^{*}
\end{array}\right)=\mathbf{a}_{11}^{-1} \mathbf{b}_{11}(L)\left(\begin{array}{c}
\widehat{p}_{t-1}^{x} \\
\widehat{\pi}_{t-1}^{m *} \\
\widehat{r}_{t-1}^{*}
\end{array}\right)+\mathbf{a}_{11}^{-1}\left(\begin{array}{c}
\epsilon_{t}^{p^{x}} \\
\epsilon_{t}^{\pi^{m *}} \\
\epsilon_{t}^{r^{*}}
\end{array}\right)
$$

The estimated coefficients of this system are presented in table 6. The regression includes, for each equation, a constant and a deterministic trend, whose estimates are not shown. 


\section{Footnotes}

${ }^{1}$ Calvo (1979) finds that inflation targeting renders the rational expectations equilibrium indeterminate. This is not the case in our model. Two important elements distinguish our theoretical framework from Calvo's: the presence of sticky prices and the fact that money affects aggregate activity through aggregate demand rather than through aggregate supply.

${ }^{2}$ However, a policy that ensures that $\pi_{t+1}^{n}=\bar{\pi}^{n} \forall t \geq 0$ does not imply (27), because in that case marginal revenue may deviate from marginal cost in response to unanticipated shocks.

${ }^{3} \mathrm{~A}$ closed economy model in which (27) represents the optimal monetary arrangement is studied by Rotemberg and Woodford (1999). The small open economy case is analyzed in Galí and Monacelli (2000).

${ }^{4}$ One can show that $p^{T}=p^{x} / G_{1}\left(a^{x}, a^{m}\right), G\left(a^{x}, a^{m}\right) \equiv\left(a^{x}\right)^{\frac{\alpha^{x}}{\alpha^{x}+\alpha^{m}}}\left(a^{m}\right)^{\frac{\alpha^{m}}{\alpha^{x}+\alpha^{m}}}$ and $G_{1}\left(G_{1}\left(a^{x}, a^{m}\right)\right.$ denotes the partial derivative of $G$ with respect to its first argument.

${ }^{5}$ The data source for the dollar export and import price indices for Mexico and Mexican GDP is INEGI; the Mexican peso-U.S. dollar exchange rate and the Mexican CPI were obtained from Banco de Mexico; the U.S. CPI was taken from the Bureau of Labor Statistics; and the 3-month Treasury bill rate from the Board of Governors of the Federal Reserve System.

${ }^{6}$ All equations include a constant and a linear trend. The output and real exchange rate equations include, in addition, seasonal dummies and dummies meant to reflect exchangerate regime changes. (These deterministic variables are not shown in equation (44).) The inclusion of regime-switch dummies is motivated by the fact that a number of authors have identified several exchange rate regime shifts in Mexico over the sample period we are considering. They find that these regime shifts have typically been associated with substantial macroeconomic volatility. For example, Del Negro and Obiols-Homs (2000) identify three 
distinct exchange-rate regimes since the debt crisis of the early 1980s: the period 1982:Q41987:Q4 was characterized by a dual exchange rate regime with a pre-announced schedule for the official exchange rate; the period 1988:Q2-1994:Q3 as mentioned above corresponds to the Pacto de Solidaridad Económica; and the collapse of the Pacto in December of 1994 was followed by a dirty float. Because our sample begins in 1987, which is near the end of the dual exchange rate regime, we address the regime shift problem by including only one level dummy marking the dirty float in the equations describing the evolution of real GDP and the real exchange rate.

${ }^{7}$ This approach implicitly assumes that the same monetary policy prevailed before, during, and after the Pacto era, which is clearly counterfactual. We obtain similar results if, instead, we construct time series of length 26 using the nonstochastic steady-state values as initial conditions.

${ }^{8}$ In constructing the trend of output, consumption, and investment we used the longest quarterly sample available, 1980:1-1999:2. The real exchange rate, inflation, and the trade balance-to-output ratio were detrended using the Pacto sample period. The reason for using a shorter sample in detrending these variables is that, as stressed by the supply-side explanations of the real effects of exchange-rate-based stabilization (Rebelo, 1993, Uribe, 1997, 2000), permanent reductions in inflation expectations, like the one that arguably took place in Mexico at the beginning of the Pacto era, are associated with a gradual adjustment in these variables to new long-run levels.

${ }^{9}$ Note that despite this correction, consumption is still more volatile than output. In developed countries, typically consumption is significantly less volatile than output (see Baxter and Crucini, 1995).

${ }^{10}$ Recall that the parameter determining the adjustment cost of investment was chosen so that the model's prediction for the standard deviation of investment matches the observed 
one.

${ }^{11}$ We note in addition that the sample period used to estimate the exogenous processes driving business cycles in Mexico is significantly longer than the duration of the Pacto program.

${ }^{12}$ If one proxies hours worked by the employment rate for the population 12 years of age or older, then one finds a value of $\xi$ of 0.45 percent using total consumption and 0.21 percent using our measure of nondurables. Because employment is typically less volatile than actual hours worked, all other things equal, using this series as a measure of hours is likely to bias the welfare costs downward.

${ }^{13}$ Alternatively, the figures shown in table 5 can be interpreted as follows. The difference in the welfare cost of dollarization and that associated with another monetary policy indicates the fraction by which the sequence of consumption under dollarization would have to be increased in every period for agents to be indifferent between dollarization and the alternative monetary policy. For example, to make agents as well off under dollarization as under CPI inflation targeting, the stream of consumption in the dollarized economy would have to be increased by 0.11 percent at every date and state.

${ }^{14}$ CECORs (Certificados de Cancelación de Obligaciones de la Provincia de Córdoba) were issued as two-year bearer bonds denominated in pesos paying an annual interest rate of 12 percent. CECORs were issued in denominations as low as five pesos, which is the equivalent of five U.S. dollars. 
Table 1: Variance Decomposition of Mexican Output and Real Exchange Rate Sample: 1987:Q1 to 1999:Q2

\begin{tabular}{ccccc}
\hline \hline & \multicolumn{3}{c}{$\begin{array}{c}\text { Percent of k-quarter ahead forecasting error variance } \\
\text { explained by external and domestic disturbances }\end{array}$} \\
\cline { 2 - 5 } $\mathrm{k}$ & \multicolumn{2}{c}{ Output } & \multicolumn{2}{c}{ Real Exchange Rate } \\
\cline { 2 - 5 } & external shocks & domestic shocks & external shocks & domestic shocks \\
\hline 4 & 26 & 74 & 35 & 65 \\
8 & 45 & 55 & 44 & 56 \\
12 & 64 & 36 & 46 & 54 \\
16 & 68 & 32 & 47 & 53 \\
\hline \hline
\end{tabular}


Figure 1: Model's response to a persistent world interest rate shock

_ : Money growth rate peg _ - - : Dollarization

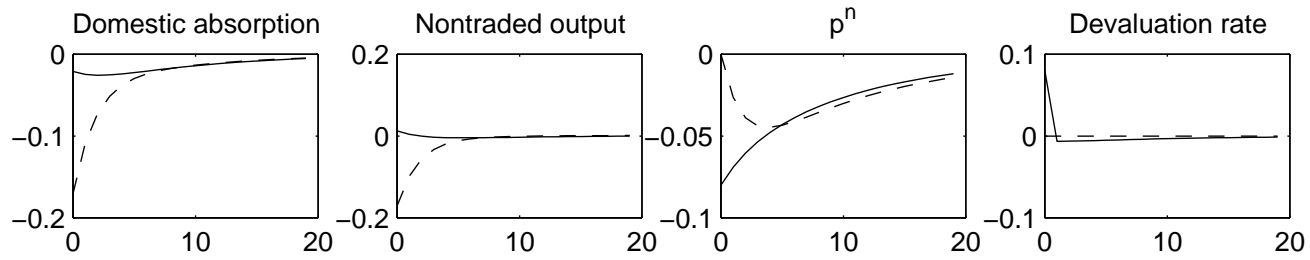

\section{— : Targeting CPI inflation - - - : Dollarization}

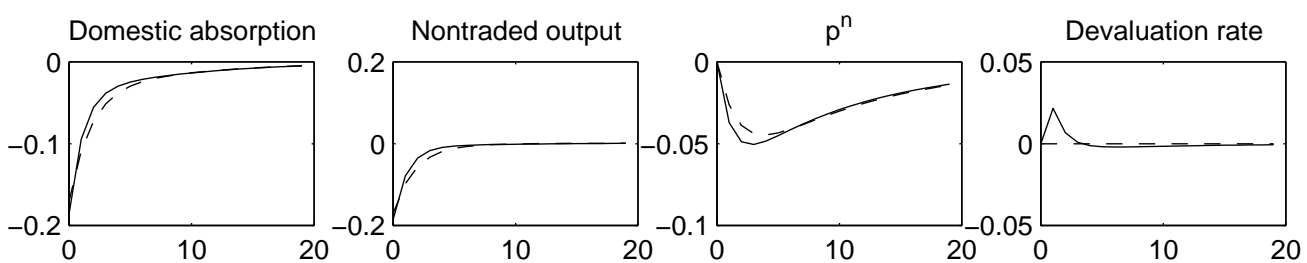

— : Targeting nontraded inflation
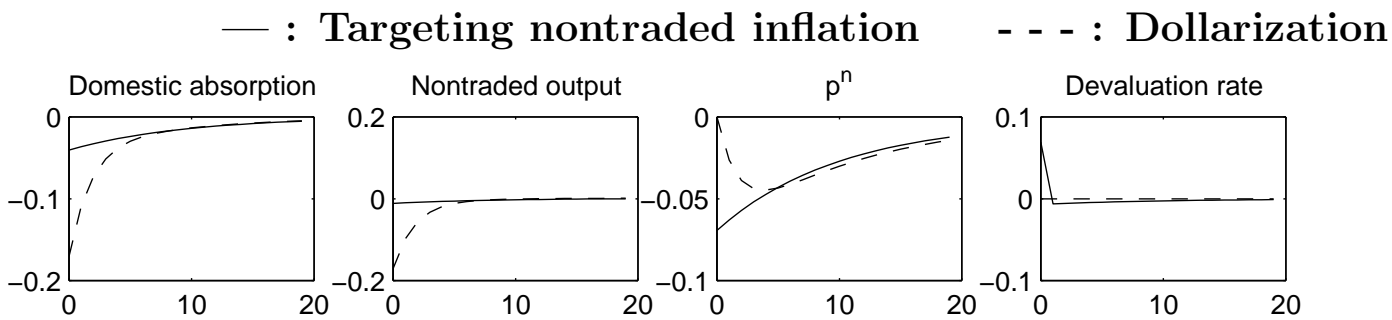

- : Devaluation rate rule - - - : Dollarization
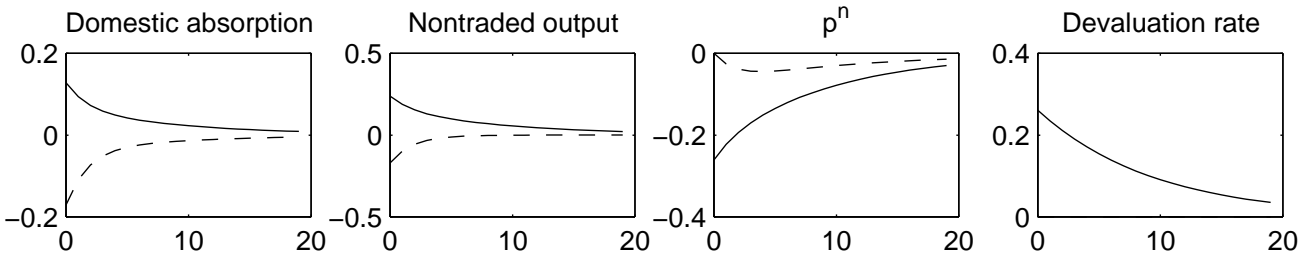

- : Ad hoc devaluation rate rule
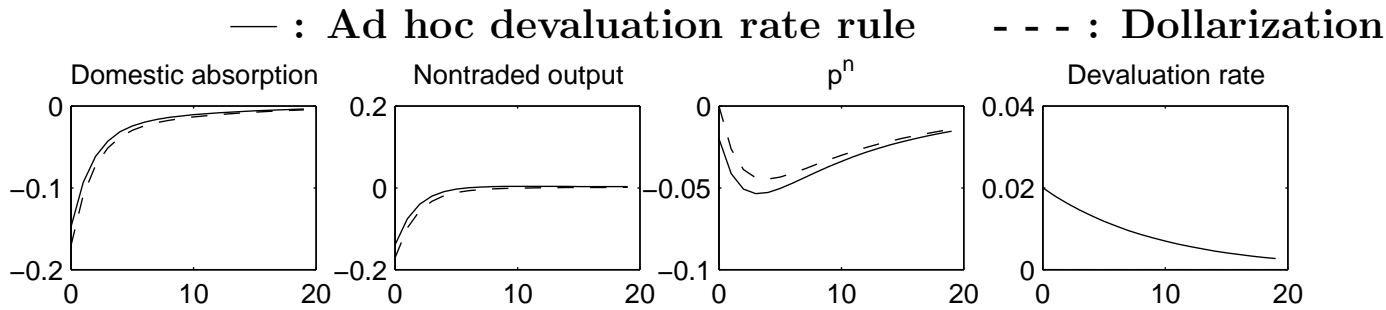
Figure 2: The CECOR: How Córdoba abandoned pesoization 
Table 2: Calibrated parameters

\begin{tabular}{ccrl}
\hline \hline Symbol & Definition & Value & Description \\
\hline$s_{x}$ & $\frac{p^{x} q^{x}}{p g d p}$ & 0.442 & share of traded value added in GDP \\
$s_{t b}$ & $\frac{p^{x}\left(q^{x}-a^{x}\right)-a^{m}}{p g d p}$ & 0.036 & trade balance to GDP ratio \\
$s_{x x}$ & $\frac{p^{x}\left(q^{x}-a^{x}\right)}{p g d p}$ & 0.240 & export share in value added \\
$\frac{r}{\pi^{m}}$ & & 1.065 & gross annual world real interest rate \\
$\epsilon$ & & 1.0157 & gross quarterly devaluation rate \\
$s_{h x}$ & $\frac{w h^{x}}{p^{x} q^{x}}$ & 0.261 & labor share in exportable sector \\
$s_{h n}$ & $\frac{w h^{n}}{p^{n} q^{n}}$ & 0.359 & labor share in nontraded sector \\
$\eta_{m i}$ & $\frac{\partial \ln m}{\partial \ln \frac{i}{1+i}}$ & -0.16 & log-log interest elasticity of money demand \\
$s_{i}$ & $\frac{(1+s(v)) p i}{p g d p}$ & 0.217 & investment share in GDP \\
$\eta_{\phi \phi}$ & $\frac{\phi^{\prime \prime}(\delta) \delta}{\phi^{\prime}(\delta)}$ & -0.13 & minus elasticity of Tobin's Q w.r.t. investment \\
$\mu$ & $\frac{p^{n}-m c}{m c}$ & 0.1 & markup of prices over marginal cost \\
& $\frac{\theta^{\prime \prime}\left(\pi^{n}\right) \pi^{n 2}}{p^{n} q^{n}}$ & 175 & markup coefficient in new-Keynesian \\
$\eta_{\theta}$ & $\frac{P \cdot G D P}{M 1}$ & 3.92 & quarterly GDP money velocity \\
& $\frac{U_{C C} C}{U_{C}}$ & -5 & steady state labor-to-leisure ratio \\
$v_{G D P}$ & $\frac{\partial \ln r_{t}}{\partial \ln \left(-b_{t}\right)}$ & $10^{-5}$ & debt elasticity of country interest rate premium \\
$\frac{h}{1-h}$ & & & in the nontraded sector \\
$\eta_{c c}$ & &
\end{tabular}


Table 3: Implied parameters

\begin{tabular}{|c|c|c|c|c|}
\hline Symbol & Definition & Restriction & Value & Description \\
\hline$\beta$ & & $\overline{\pi^{m} / r}$ & 0.9844 & discount factor \\
\hline$s_{n}$ & $\frac{p^{n} q^{n}}{p g d p}$ & $1-s_{x}$ & 0.558 & share of nontraded value added in GDP \\
\hline$s_{k x}$ & $\frac{u k}{p^{x} q^{x}}$ & $1-s_{h x}$ & 0.739 & capital share in the traded sector \\
\hline$s_{h}$ & $\frac{w h^{x}+w h^{n}}{p g d p}$ & $s_{h x} s_{x}+s_{h n} s_{n}$ & 0.316 & labor share in GDP \\
\hline$s_{c}$ & $\frac{(1+s(v)) p c}{p g d p}$ & $1-s_{i}-s_{t b}$ & 0.747 & consumption-to-GDP ratio \\
\hline$\gamma$ & $s(v) \equiv A v^{\gamma}$ & $-\frac{1+\eta_{m i}}{\eta_{m i}}$ & 5.25 & velocity elasticity of transaction cost \\
\hline$v$ & $\frac{p(c+i)}{m}$ & $\left(1-s_{t b}\right) v_{G D P}-\frac{r \epsilon-1}{r \epsilon \gamma}$ & 3.77 & absorption velocity of money \\
\hline$A$ & $s(v)=A v^{\gamma}$ & $\frac{(r \epsilon-1)}{r \epsilon \gamma v^{1+\gamma}}$ & $1.46 \times 10^{-6}$ & scale factor in transaction cost function \\
\hline$\delta$ & & $\frac{\left(r / \pi^{m}-1\right) s_{i}}{\frac{s_{k K}(1+s(v))}{\left[1+s(v)+v v^{\prime}(v)\right]}-s_{i}}$ & 0.129 & annual capital depreciation rate \\
\hline$\nu$ & & $\frac{1}{1+\frac{1-h}{h} \frac{s_{h}(1+s(v))}{s_{c \mid}\left(1+s(v)+v s^{\prime}(v) \mid\right.}}$ & 0.374 & preference parameter (see eqn. 2) \\
\hline$\sigma$ & & $1-\frac{1+\eta_{c c}}{\nu}$ & 11.71 & preference parameter (see eqn. 2 ) \\
\hline$\alpha^{n}$ & $\frac{F_{n}^{f} a^{n}}{F^{f}}$ & $\frac{1-s_{x}}{1-s_{t b}}$ & 0.579 & elasticity of $F^{f}$ w.r.t. $a^{n}$ \\
\hline$\alpha^{x}$ & $\frac{F_{x}^{f} a^{x}}{F^{f}}$ & $\frac{s_{x}-s_{x x}}{1-s_{t h}}$ & 0.210 & elasticity of $F^{f}$ w.r.t. $a^{x}$ \\
\hline$\alpha^{m}$ & $\frac{F_{m}^{f} a^{m}}{F^{f}}$ & $\frac{s_{x x}-s_{t b}}{1-s_{t b}}$ & 0.211 & elasticity of $F^{f}$ w.r.t. $a^{m}$ \\
\hline$\omega$ & $\frac{F^{n} h^{n}}{F^{n}}$ & $s_{h n}(1+\mu)$ & 0.395 & elasticity of $F^{n}$ w.r.t. $h^{n}$ \\
\hline$\alpha^{k}$ & $\frac{F_{k}^{x} k^{x}}{F^{x}}$ & $s_{k x}$ & 0.739 & elasticity of $F^{x}$ w.r.t. $k^{x}$ \\
\hline $1-\alpha^{k}$ & $\frac{F_{h}^{x} h^{x}}{F^{x}}$ & $s_{h x}$ & 0.261 & elasticity of $F^{x}$ w.r.t. $h^{x}$ \\
\hline
\end{tabular}


Table 4: Actual and Predicted Comovements

Sample: 1988:2 - 1994:3

\begin{tabular}{lcccccc}
\hline \hline & $g d p_{t}$ & $c_{t}$ & $i_{t}$ & $\pi_{t}$ & $\frac{t b_{t}}{g d p_{t}}$ & rer $_{t}$ \\
\hline $\begin{array}{lcccccc}\text { Percent std. dev. } \\
\text { Mexican data }\end{array}$ & 3.32 & 3.65 & 12.12 & 1.79 & 1.38 & 3.27 \\
$\quad$ Model & 2.38 & 2.14 & 12.36 & 1.32 & 3.50 & 1.98 \\
Serial corr. & & & & & & \\
$\begin{array}{l}\text { Mexican data } \\
\text { Model }\end{array}$ & 0.88 & 0.90 & 0.95 & 0.12 & 0.13 & 0.81 \\
Corr. with GDP & 0.40 & 0.46 & 0.53 & 0.12 & 0.49 & 0.50 \\
$\quad$ Mexican data & 1.00 & 0.94 & 0.97 & 0.24 & -0.10 & -0.00 \\
Model & 1.00 & 0.82 & 0.21 & 0.74 & 0.11 & 0.75 \\
\hline \hline
\end{tabular}


Table 5: The welfare costs of Mexican business cycles under alternative monetary policy regimes

(Measured in percentage points of nonstochastic steady-state consumption)

\begin{tabular}{llc}
\hline \hline Monetary Policy & Specification & Welfare Cost \\
\hline Dollarization & $\widehat{\epsilon}_{t}=0$ & 0.27 \\
Money growth rate peg & $M_{t}=(1+\zeta) M_{t-1}$ & 0.17 \\
Inflation targeting & & \\
$\quad \widehat{\pi}_{t}=0$ & 0.16 \\
$\quad$ CPI inflation & $m r_{t}=m c_{t}$ & 0.18 \\
$\quad$ Nontraded inflation & & 0.01 \\
Devaluation rate rule & & 0.15 \\
$\quad$ Constrained optimal & $\widehat{\epsilon}_{t}=-0.5 \widehat{p}_{t}^{x}-2.2 \widehat{\pi}_{t}^{m^{*}}+26.1 \widehat{r}_{t}^{*}$ & 0.33 \\
$\quad$ Ad hoc & $\widehat{\epsilon}_{t}=-0.5 \widehat{p}_{t}^{x}-2.2 \widehat{\pi}_{t}^{m^{*}}+2 \widehat{r}_{t}^{*}$ & \\
Estimated Pacto policy & $\widehat{\epsilon}_{t}=\eta_{t}^{\epsilon} ; \quad \sigma_{\eta^{\epsilon}}=0.0145$ & \\
\hline \hline
\end{tabular}


Table 6: Estimated law of motion of the external shocks

Quarterly data from 1987:Q1 to 1999:Q2

\begin{tabular}{lrrr}
\hline \hline & $\widehat{p}_{t}^{x}$ & $\widehat{\pi}_{t}^{m *}$ & $\widehat{r}_{t}^{*}$ \\
\hline$\widehat{p}_{t-1}^{x}$ & $\mathbf{0 . 5 4 0 4}$ & 0.0227 & 0.0004 \\
$\widehat{p}_{t-2}^{x}$ & $\mathbf{- 0 . 4 5 4 4}$ & -0.0355 & -0.0046 \\
$\widehat{p}_{t-3}^{x}$ & 0.2685 & 0.0364 & -0.0003 \\
$\widehat{p}_{t-4}^{x}$ & $\mathbf{- 0 . 3 3 3 8}$ & -0.0019 & 0.0008 \\
$\widehat{\pi}_{t-1}^{m *}$ & -0.1278 & 0.2640 & $\mathbf{0 . 0 4 4 4}$ \\
$\widehat{\pi}_{t-2}^{m *}$ & -0.2470 & -0.2371 & -0.0159 \\
$\widehat{\pi}_{t-3}^{m *}$ & 1.4127 & -0.1702 & 0.0174 \\
$\widehat{\pi}_{t-4}^{m *}$ & $\mathbf{- 2 . 0 3 6 5}$ & 0.0256 & 0.0007 \\
$\widehat{r}_{t-1}^{*}$ & 13.5131 & 0.6295 & $\mathbf{1 . 4 1 7 8}$ \\
$\widehat{r}_{t-2}^{*}$ & -14.5399 & 1.4187 & -0.4831 \\
$\widehat{r}_{t-3}^{*}$ & 1.3230 & -3.2075 & 0.0427 \\
$\widehat{r}_{t-4}^{*}$ & 5.6132 & 0.2461 & -0.0307 \\
$\epsilon_{t}^{p^{x}}$ & 1 & 0.0515 & 0.0035 \\
$\epsilon_{t}^{\pi^{m *}}$ & 0 & 1 & 0.0596 \\
$\epsilon_{t}^{r^{*}}$ & 0 & 0 & 1 \\
$\bar{R}^{2}$ & 0.54 & 0.45 & 0.96 \\
$\mathrm{D} . \mathrm{W}$. & 2.13 & 1.93 & 1.92 \\
Nobs. & 50 & 50 & 50 \\
\hline \hline
\end{tabular}

Note. Bold face indicates that the coefficient estimate is significant at the 10 percent level. $\widehat{p}_{t}^{x}$ denotes the log-deviation of the terms of trade from trend, $\widehat{\pi}_{t}^{m *}$ denotes logdeviation of gross import price inflation from trend, and $\widehat{r}_{t}^{*}$ denotes the log-deviation of the gross yield on 3-month U.S. Treasury bills from trend. The standard deviations of $\epsilon_{t}^{p^{x}}, \epsilon_{t}^{\pi^{m *}}$, and $\epsilon_{t}^{r^{*}}$ are, respectively, 0.0343, 0.0045, and 0.0006 . 